\title{
HUBUNGAN BIOFILM DENGAN INFEKSI : IMPLIKASI PADA KESEHATAN MASYARAKAT DAN STRATEGI MENGONTROLNYA
}

\author{
Rini Purbowati \\ Bagian Biomedik \\ Fakultas Kedokteran Universitas Wijaya Kusuma-Surabaya \\ Email: purbowatirini@gmail.com
}

\begin{abstract}
Abstrak
Biofilm yang terbentuk di permukaan mukosa rongga tubuh dapat menjadi sumber utama infeksi. Infeksi oleh mikroba pembentuk biofilm sulit untuk diobati karena mereka ketahanan yang lebih besar terhadap agen antimikroba dibandingkan sel-sel individunya. Oleh karena itu infeksi yang terkait biofilm semakin menambah beban ekonomi negara. Tujuan dari tinjauan pustaka ini adalah memperkaya literatur tentang biofilm dan mikroba pembentuk biofilm dan kontribusinya terhadap penyakit yang menyerang manusia dengan tujuan menarik perhatian publik terhadap implikasi kesehatan masyarakat. Biofilm didefinisikan sebagai sekumpulan dari mikroorganisme dan produk ekstraselular yang berasosiasi pada permukaannya dan umumnya menempel pada substrat biologi dan non-biologi. Pembentukan biofilm dipengaruhi oleh faktor pengontrol perlekatan sel, sifat alami permukaan, karakteristik media, serta karakteristik permukaan sel mikroba. Secara genetik kemampuan pembentukan biofilm diatur oleh operon ica ABDC. Siklus kehidupan pada biofilm meliputi perlekatan sel, pembentukan mikrokoloni, pembentukan biofilm serta pemantapan dan perluasan biofilm. Struktur biofilm terdiri dari mikroorganisme dan zat polimer ekstraseluler dengan struktur vertikalseperti menara atau jamur yang dipisahkan oleh ruang interstitial. Bakteri pembentuk biofilm menunjukkan peningkatan resistensi terhadap antibiotik dan desinfektan serta resisten terhadap proses fagositosis dan mekanisme lain dari sistem imun bawaan dan adaptif. Biofilm berperan dalam kasus keracunan makanan dan mempengaruhi keamanan pangan. Biofilm telah diketahui terlibat dalam berbagai macam infeksi mikroba pada tubuh seperti infeksi saluran kemih, infeksi kateter, infeksi telinga tengah, pembentukan gigi plak, gingivitis, legionellosis, infeksi pada pemakaian lensa kontak, dan endokarditis, infeksi pada cystic fibrosis, dan infeksi implan permanen seperti prostesis persendian dan katup. Sehingga perlu diperhatikan oleh instansi pemerintah dengan menginstruksikan kepada seluruh pemerhati kesehatan masyarakat dan lingkungan untuk mengembangkan dan mengembangkan penilaian risiko kesehatan yang tepat dan pedoman khusus infeksi terkait biofilm yang melindungi kesehatan masyarakat sekaligus lingkungan.
\end{abstract}

Kata Kunci : biofilm, penyakit, implikasi, kesehatan masyarakat. 


\title{
CORRELATION BIOFILM WITH INFECTION: IMPLICATIONS FOR PUBLIC HEALTH AND STRATEGIES TO CONTROL
}

\begin{abstract}
Biofilms are formed in the surfaces of mucosal of the body cavity can be a major source of infection. Infection by microbial biofilm formers are difficult to treat because of their greater resistance to antimicrobial agents than individual cells. Therefore biofilm-related infections and increased the economic burden of the country. The purpose of this literature review is to examine literature on biofilms and biofilm-associated microbes and their contribution to the disease burden of man with the aim of drawing attention to their public health implication.Biofilm are defined as "collections of microorganisms and their associated extracellular products at an interface and generally attached to a biological and nonbiological substratum. Biofilm formation are influenced by factors controlling cell attachment, nature of surface, propertis of medium, and properties of the microbial cell surface. The ability of biofilm formation is genetically regulated by ica ABDC operon. Biofilm life cycle include adhesion of cells, formation of microcolonies, formation of biofilm and detachment anddispersal of biofilm. Structure of biofilm consists microorganisms and extracellular polymeric substances with vertical structures of microorganisms sometimes take the form of towers or mushrooms which are separated by interstitial spaces. Bacterial biofilm showed increased resistance to antibiotics, disinfectants and resistant to phagocytosis and other mechanisms of innate and adaptive immune system. Biofilms associated with food borne illness and affect to food security. Biofilms have been implicated in a wide variety of microbial infections in the body such as as urinary tract infections, catheter infections, middle-ear infections, formation of dental plaque, gingivitis, legionellosis ,infections involving contact lenses, and less common but more lethal processes such as endocarditis, infections in cystic fibrosis, and infections of permanent indwelling devices such as joint prostheses and heart valves. It is important for government agencies with a mandate for safeguarding public health and environment to develop and adopt ap propriate health risk assessment and biofilm-specific guidelines that are protective of both public health and the environment.
\end{abstract}

Keywords: biofilm, implications, diseases, public health.

\section{PENDAHULUAN}

Pada kebanyakan habitat alami, mikroorganisme tidak berada dalam bentuk individu, atau sel yang hidup bebas tetapi mereka berasosiasi dengan mikroorganisme lain atau melekat dipermukaan. yang sering disebut sebagai biofilm 1. Bukti menunjukkan bahwa dalam lingkungan alaminya, lebih dari
99\% mikroba hidup pada mikro-ekosistem sebagai biofilm ${ }^{2}$. Menurut Riemann and Cliver (2006), biofilm didefinisikan sebagai sekumpulan dari mikroorganisme dan produk ekstraselular yang berasosiasi pada permukaannya dan umumnya menempel pada substrat biologi dan nonbiologi ${ }^{3}$. 
Dalam beberapa kasus, biofilm tersebut dihuni oleh spesies tunggal sedangkan kasus lainnya, di diami oleh mikroba yang beragam. Banyak permukaan yang jika dilihat dari gabungan antara kelembaban dan nutrisi yang ada didalamnya rentan terhadap pembentukan biofilm jika ada mikroorganisme yang hadir. Beberapa permukaan tersebut meliputi jaringan hidup, perangkat medis, perpipaan sistem pengolahan air minum dan industri dan system akuatik alami yang mendukung pembentukan biofilm ${ }^{2}$. Biofilm tersusun atas eksopolisakarida bakteri dan material capsular yeast dan menyediakan lapisan pelindung bagi mikroba sehingga terlindung terhadap proses desikasi, paparan antimikroba dan agen pembersih. Bila biofilm terbentuk di permukaan mukosa yang melindungi rongga tubuh maka dapat menjadi sumber utama infeksi 1. Mikroba pembentuk biofilm terlibat dalam sejumlah infeksi manusia yang sulit untuk diobati yang memiliki konsekuensi terhadap kesehatan masyarakat meskipun ada beberapa aplikasi biofilm yang bermanfaat.

Mikroba pembentuk biofilm memiliki ketahanan yang lebih besar terhadap agen antimikroba dibandingkan sel-sel individunya. Agen antimikroba umumnya jauh lebih efektif melawan sel yang aktif, hal ini berarti bahwa disinfektan yang efektif untuk sel planktonik belum tentu efektif untuk sel biofilm ${ }^{3}$. Dilihat dari resistensinya terhadap metode kontrol mikroba secara tradisional, mikroba pembentuk biofilm menyebabkan manusia menjadi lebih virulen terhadap penyakit dalam jangka waktu yang lama dengan pilihan pengobatan yang terbatas sehingga menyebabkan peningkatan angka kematian dan peningkatan biaya pengobatan ${ }^{2}$. Menurut beberapa perhitungan secara ekonomi, beban ekonomi infeksi yang timbul dari biofilm sebesar 6 miliar dolla per tahun di Amerika Serikat ${ }^{4}$. Sayangnya, sebagian besar metode kontrol mikroba yang ada saat ini hanya menargetkan satu sel atau sel yang hidup bebas saja (planktonik) karena apresiasi yang signifikan terhadap biofilm masih merupakan fenomena yang relatif baru ${ }^{2}$. Tujuan dari tinjauan pustaka ini adalah untuk memperkaya literatur tentang biofilm dan mikroba pembentuk biofilm dan kontribusinya terhadap penyakit yang menyerang manusia dengan tujuan menarik perhatian publik terhadap implikasi kesehatan masyarakat . 


\section{TINJAUAN PUSTAKA}

\section{DEFINISI BIOFILM}

Beberapa peneliti telah memberikan definisi mengenai biofilm diantaranya adalah menurut ${ }^{5}$ menyebutkan bahwa biofilm merupakan suatu asosiasi mikroorganisme di mana sel-sel mikroba menempel satu sama lain pada permukaan hidup maupun permukaan tak-hidup dalam suatu matriks yang diproduksi oleh dirinya sendiri dari bahan polimer ekstraseluler. biofilm merupakan kelompok kompleks dari sel mikroba yang menempel dalam matriks eksopolisakarida pada permukaan perangkat medis dimana infeksi yang terkait biofilm dalam peralatan medis menimbulkan masalah serius bagi kesehatan masyarakat dan mempengaruhi fungsi perangkat medis tersebut 6 . Sedangkan menurut Bogino ${ }^{7}$, biofilm merupakan komunitas bakteri di mana selsel yang tertanam dalam matriks senyawa polimer ekstraselular yang melekat di permukaan. Hidup dalam biofilm membantu melindungi bakteri dari kondisi yang tidak menguntungkan dan pembentukan biofilm tampaknya menjadi faktor penting dalam siklus penyakit dari patogen bakteri baik pada manusia dan hewan. Biofilm biasanya terdiri dari beragam mikroorganisme, yang melekat pada permukaan. Mikroorganisme ini biasanya tertanam dalam matriks polimer 8. Biofilm digambarkan sebagai koloni mikroorganisme yang melekat satu sama lain pada permukaan, dalam bentuk yang irreversibel ${ }^{9}$. Sebuah biofilm didefinisikan sebagai ekosistem mikrobiologi kompleks yang terbentuk oleh spesies tunggal atau banyak spesies (multispesies) terkait dengan matriks polimer organik ${ }^{10}$. Mayoritas bakteri hidup tidak berada dalam bentuk planktonik, tetapi sebagai anggota dari komunitas biofilm yang melekat. Bentuk populasi tersebut didefinisikan sebagai 'mikroba tertutup matriks, yang melekat baik pada permukaan biologis maupun non-biologis'. Bakteri pembentukan biofilm terlibat pada banyak penyakit kronis di banyak negara. 11. Secara alami mikroorganisme melekat pada permukaan yang lembab, berkembang biak dan membenamkan selnya dalam matriks berlendir yang terdiri dari zat polimer ekstraseluler (EPS) yang mereka hasilkan dan membentuk biofilm. Biofilm dapat menjadi bermasalah pada sektor industri makanan tertentu seperti pembuatan bir, pengolahan susu, pengolahan produk segar, pengolahan unggas dan pengolahan daging merah ${ }^{12}$. 


\section{STRUKTUR DAN KOMPOSISI BIOFILM}

Biofilm $\begin{gathered}\text { terdiri } \\ \text { mikroorganisme dan } \\ \text { zat }\end{gathered}$ polimer
ekstraseluler yang diproduksi oleh mereka
sendiri yang disebut
eksopolisakarida (EPS). Perkembangan
biofilm yang utuh mengandung banyak
lapisan termasuk matriks EPS dengan
struktur vertikal, dan pembentukan film.
Struktur vertikal mikroorganisme kadang-
kadang berbentuk seperti menara atau
jamur yang dipisahkan oleh ruang
interstitial. Ruang $\quad$ interstitial
memungkinkan sebagian besar biofilm
dengan mudah dan cepat mengambil
nutrisi dari cairan sekitarnya dan
memindahkan produk sampingannya dari
biofilm. Pembentukan biofilm memang
kompleks, tapi secara umum dapat
dikelompokkan dalam empat langkah
dasar yaitu: deposisi dan pembentukan
film, mikroba (planktonik) melekat pada
lembaran film, pertumbuhan dan
kolonisasi bakteri dan akhirnya
terbentuklah biofilm ${ }^{13}$.

\section{SIKLUS KEHIDUPAN PADA BIOFILM}

a. Perlekatan sel

Perlekatan mikroorganisme pada permukaan tertentu dapat terjadi secara aktif atau pasif, tergantung pada motilitas bakteri atau transportasi dari sel planktonik oleh gravitasi, difusi atau kekuatan dinamis cairan dari fase cairan disekitarnya. Perlekatan juga tergantung pada ketersediaan hara dalam media sekitarnya, dan tahap pertumbuhan sel bakteri itu sendiri. Dua tahapan yang dapat diidentifikasi dalam proses ini yaitu perlekatan reversibel diikuti oleh perlekatan irreversibel. Awalnya, interaksi jangka panjang terbentuk antara sel bakteri dan substrat disebut perlekatan reversibel, dan melibatkan interaksi van der Waals, gaya elektrostatik dan interaksi hidrofobik. Selama tahap ini, bakteri masih menunjukkan gerak Brown dan dapat dengan mudah dihilangkan dengan gaya geser fluida (misalnya hanya dengan membilasnya). Kemudian dilanjutkan perlekatan irreversibel, interaksi jangka pendek yang melibatkan interaksi dipol-dipol, ion hidrogen, dan ikatan kovalen, dan interaksi hidrofobik.

Interaksi antara bakteri dan permukaan terjadi terutama melalui alat pelengkap bakteri seperti flagela, fimbriae, pili dan fibril, dan pengangkatan sel membutuhkan energi yang lebih kuat seperti 
scrubbing atau menggores. Suhu dan $\mathrm{pH}$ permukaan kontak memiliki pengaruh pada tingkat perlekatan mikroorganisme.

b. Pembentukan mikrokoloni

Proliferasi sel-sel bakteri yang melekat secara irreversibel dapat terjadi dengan menggunakan nutrisi yang ada di lingkungan cairan sekitarnya. Ini mengarah pada pembentukan mikrokoloni yang membesar dan menyatu untuk membentuk lapisan sel yang menutupi permukaan. Sel-sel yang melekat menghasilkan polimer tambahan (eksopolisakarida), yang membantu dalam perlekatan sel-sel ke permukaan dan dalam menstabilkan koloni dari fluktuasi lingkungan.

c. Pembentukan biofilm

Pembentukan biofilm adalah konsekuensi dari perlekatan terus menerus sel bakteri terhadap substrat dan pertumbuhan selanjutnya, bersama dengan produksi EPS. Komposisi biofilm dapat heterogen karena kolonisasi oleh mikroorganisme yang berbeda dengan kebutuhan gizi yang berbeda. Peningkatan ukuran biofilm yang lebih besar dapat terjadi melalui deposisi atau perlekatan dari bahanbahan organik dan anorganik yang terlarut lainnya dan partikel dari fase cair di sekitarnya.

d. Pemantapan dan perluasan biofilm

Setelah terbentuk biofilm matang, bakteri yang menempel tersebut untuk bertahan hidup dan membuat relung baru harus mampu melepaskan diri dan menyebar dari biofilm. Sel anak dapat menjadi individu baru atau terkelupas. Bakteri yang terlepas kemudian dapat berpindah ke lokasi baru dan memulai kembali proses biofilm ${ }^{3}$.

\section{FAKTOR PERLEKATAN MIKROBA}

Pertamakali pembentukan biofilm dimulai ketika bakteri menemukan dan dapat melekat pada kondisi permukaan melalui molekul organik kecil. Tingkat perlekatan sel mikroba diatur oleh faktorfaktor seperti sifat permukaan, kondisi lapisan permukaan, karakteristik dan hidrodinamika dari media cair, berbagai karakteristik permukaan sel mikroba, regulasi gen dan kuorum sensing ${ }^{2}$. 
Pembentukan biofilm dapat terjadi diberbagai jenis permukaan dan berbagai kondisi lingkungan dimana bakteri berada. Bakteri, molekul organik dan anorganik yang berada di permukaan kemudian membentuk kondisi film. Substrat organik dan anorganik ini bersama-sama dengan mikroorganisme berpindah ke permukaan melalui difusi atau mengikuti aliran cairan. Transfer nutrisi lebih tinggi dalam biofilm daripada fase cair ${ }^{3}$.

Kondisi film penting dalam proses perlekatan. Polimer organik dari media yang permukaannya terendam sehingga mempengaruhi tingkat dan kekuatan perlekatan mikroba. Kondisi film terbentuk dalam beberapa menit pemaparan, dan terus berkembang selama beberapa jam. Sejumlah host memproduksi film seperti darah, air mata, urin, saliva, cairan intravaskular dan sekresi pernapasan mempengaruhi perlekatan bakteri terhadap biomaterial 14 . Karakteristik media cair, seperti pH, tingkat nutrisi, kekuatan ion, dan temperatur, juga mungkin memainkan peran dalam tingkat perlekatan mikroba pada permukaan. Sebagai contoh, peningkatan jumlah sel bakteri yang melekat diyakini sebagai akibat dari peningkatan konsentrasi nutrisi dalam media dan juga peningkatan konsentrasi beberapa kation. Selain itu, sifat hidrodinamik dari media cair seperti karakteristik kecepatan cairan mempengaruhi tingkat dan luasnya perlekatan $^{2}$.

Tingkat dan kekuatan perlekatan sel mikroba dipengaruhi oleh sifat permukaan sel seperti produksi zat polimer ekstraseluler (EPS), hidrofobisitas permukaan sel, kehadiran fimbriae dan flagela. Hidrofobik dari permukaan sel yang merupakan peran dari keberadaan fimbriae merupakan hal yang penting dalam adhesi karena interaksi hidrofobik cenderung meningkat dengan meningkatnya sifat non-polar dari permukaan yang terlibat. Bukti menunjukkan bahwa flagella memainkan peran penting dalam tahap awal perlekatan bakteri dengan mengatasi kekuatan terkait dengan substratum dan protein permukaan juga memainkan peran dalam perlekatan. EPS dan lipopolisakarida lebih penting dalam perlekatan untuk bahan hidrofilik. Oleh karena itu sel yang motil melekatan lebih banyak dan sel yang melawan arus lebih cepat daripada strain non - motil $^{2}$. 
Menurut O'Gara ${ }^{15}$, beberapa faktor bakteri dan faktor eksternal berpengaruh terhadap perlekatan bakteri dan pembentukan biofilm, produksi extracellular polysaccharide adhesion, yang disebut polisakarida interseluler adhesin (PIA) atau polimer $\mathrm{N}$ - asetil glukosamin (PNAG) diatur oleh enzim yang dikodekan operon ica, saat ini mekanisme pembentukan biofilm yang telah dipahami secara baik adalah pada kelompok Staphylococci.

Produk dari gen ica A adalah protein transmembran yang homolog dengan $\mathrm{N}$-asetil-glucosaminyltransferase, yang membutuhkan produk gen ica D untuk aktivitas optimalnya. Oligomer $\mathrm{N}$ asetil-glukosamin yang diproduksi oleh ica AD mencapai panjang maksimal 20 residu dan itu hanya terjadi ketika ica AD coexpressed dengan ica $\mathrm{C}$, yang diduga mengkode protein membran, yang rantai oligomernya lebih panjang. ica $\mathrm{C}$ juga mungkin terlibat dalam translokasi perpanjangan polisakarida di permukaan sel. Protein ica B yang melekat dipermukaan kemudian bertanggung jawab terhadap deasetilasi dari molekul poli-Nasetilglukosamin ${ }^{15}$.
Kemampuan untuk melekat dan membentuk biofilm pada permukaan host dianggap menjadi faktor virulensi penting pada S. epidermidis dan $S$. aureus. Pembentukan biofilm dipengaruhi oleh sejumlah faktor di antaranya, yang paling penting adalah sintesis dari polisakarida antar adhesi (PIA) oleh organisme tersebut. Enzim yang diperlukan untuk sintesis PIA dikodekan dalam operon ica ADBC, mutasi terhadap gen tersebut menghasilkan kapasitas pembentukan biofilm berkurang baik pada $S$. aureus dan S. epidermidis. Operon ica pertama kali diidentifikasi dan dipelajari paling luas pada S. epidermidis dan kemudian terbukti juga ditemukan pada $S$. aureus. Kebanyakan strain S. aureus tampaknya mengandung seluruh operon ica, meskipun ada laporan yang bertentangan. Namun, dampak klinis locus ica dan produksi PIA masih kurang baik jelas dijelaskan dalam S. aureus. Operon ica pada S. epidermidis dan S. aureus diatur oleh faktor lingkungan tetapi ekspresinya lebih dikontrol secara ketat pada $S$. aureus. Rendah tingkat ekspresi biofilm di bawah kondisi pertumbuhan in vitro terjadi pada S. aureus dan kemampuan pembentuk biofilm secara vitro sangat tergantung pada jenis strain dari S. aureus ${ }^{16}$. 


\section{PENGARUH BIOFILM TERHADAP}

\section{KEHIDUPAN MANUSIA}

Biofilm telah diketahui terlibat dalam berbagai macam infeksi mikroba pada tubuh. Pembentukan biofilm juga telah tercatat sebagai strategi pertahanan diri patogen. Beberapa mikroorganisme dalam biofilm bahkan dapat memodulasi potensi bakteri patogen lain seperti terlihat dari bakteri kariogenik pada plak biofilm. Menurut pernyataan resmi terbaru dari National Institutes of Health, lebih dari $65 \%$ dari semua infeksi mikroba disebabkan oleh biofilm. Jumlah ini mungkin tampak tinggi, tetapi jika kita ingat bahwa infeksi umum seperti saluran kemih infeksi (disebabkan oleh $E$. coli dan patogen lainnya), infeksi kateter (yang disebabkan oleh Staphylococcus aureus dan patogen gram positif lainnya), infeksi telinga tengah anak (yang disebabkan oleh Haemophilus influenzae), pembentukan plak pada gigi, dan radang gusi, yang semuanya disebabkan oleh biofilm, sulit untuk diobati atau juga sering kambuh, maka angka ini cukup realistis. Sehingga proses infeksi yang melibatkan biofilm telah terlibat pada penyakit-penyakit umum seperti infeksi saluran kemih, infeksi kateter, infeksi telinga tengah, pembentukan gigi plak, gingivitis, legionellosis, infeksi pada pemakaian lensa kontak, dan infeksi yang kurang umum namun lebih mematikan seperti endokarditis, infeksi pada cystic fibrosis, dan infeksi implan permanen seperti prostesis persendian dan katup ${ }^{13}$.

Munculnya fenomena biofilm mikroba dikaitkan dengan adanya sifat resistensi mikroba terhadap antimikroba dan sistem imun host. Sifat biologis sel bakteri pembentuk biofilm matur berbeda dari sifat biologis sel planktoniknya walaupun pada strain bakteri yang sama. Penting diketahui bahwa sifat-sifat yang diperoleh tersebut memungkinkan bakteri yang tersembunyi dalam biofilm mampu bertahan hidup di alam, terutama pada lingkungan mikro yang tidak bersahabat. Adaptasi ini memiliki konsekuensi yang cukup signifikan terhadap diagnostik dan terapi sehingga bakteri pembentuk biofilm menunjukkan peningkatan resistensi terhadap antibiotik dan desinfektan. Konsentrasi terapeutik efektif pada beberapa antibiotik terhadap bakteri dalam biofilm mungkin 100 bahkan 1000 kali lipat lebih tinggi dibandingkan bakteri bentuk planktoniknya. Selain itu, bakteri biofilm resisten terhadap proses fagositosis dan mekanisme lain dari sistem imun bawaan dan adaptif. Sehingga bakteri patogen pembentuk biofilm yang tumbuh 
menyebabkan infeksi yang persisten dan inflamasi serta kerusakan jaringan kronis.

Resistensi terhadap agen antimikroba merupakan penyebab yang paling penting dari ketidakefektifan terapi dari infeksi yang terkait biofilm. Hasil penelitian terbaru telah mengetahui ada mekanisme yang bertanggung jawab terhadap resistensi antibiotik tersebut. Pertama, biofilm yang tumbuh dikaitkan dengan peningkatan jumlah mutasi yang mengarah ke generasi bakteri yang secara fenotif resisten, dan gen yang terlibat resistensi antibiotik berkorelasi dengan fenotif biofilm. Kedua, produksi matriks eksopolisakarida berkontribusi terhadap peningkatan kelangsungan hidup sel dengan memperlambat kecepatan difusi zat antimikroba. Ketiga, perbedaan kerapatan bakteri yang mendiami biofilm menentukan gradien nutrisi dan ketersediaan oksigen, sehingga terdapat perbedaan aktivitas metabolik antara bakteri. Telah diketahui bahwa bakteri yang tidak tumbuh dan bakteri yang tumbuh lambat berkontribusi terhadap peningkatan resistensi biofilm terhadap antibiotik $^{17}$.

Mikroba pembentuk biofilm ditemukan pula pada kasus keracunan makanan dan berhubungan dengan keamanan pangan. Saat ini makanan telah diketahui menjadi suatu "kendaraan" yang mampu membawa sejumlah besar orang ke dalam potensi bahaya ${ }^{18}$. Dengan demikian, dari perspektif populasi, keracunan pangan menjadi jalur yang penting untuk transfer infeksi terkait biofilm pada manusia. Buah-buahan dan sayur-sayuran merupakan bahan pangan yang sebagai risiko tinggi sebagai sumber keracunan pangan karena kebanyakan dari mereka dimakan mentah atau diproses secara minimal. Biofilms multispesies yaitu biofilm yang terbentuk dari beberapa macam bakteri termasuk bakteri patogen manusia menempel pada permukaan tanaman sebelum dipanen yang berasal dari tanah dan lingkungan. Biofilm ini terbentuk pada jaringan tanaman sehingga dengan jelas bahwa mikroba pembentuk biofilm tidak mudah dihilangkan dengan teknik pencucian sederhana. Penyakit keracunan makanan dari konsumsi buahbuahan segar dan sayuran terjadi sebagai konsekuensi ketika buah-buahan dan sayuran yang dimakan mentah atau diproses secara minimal. Bukti 19, 20 menunjukkan bahwa keracunan pangan yang berhubungan dengan konsumsi buahbuahan segar dan sayuran telah meningkat secara dramatis selama 30 tahun terakhir karena $80 \%$ bakteri di permukaan tanaman merupakan biofilm. 


\begin{abstract}
Bakteri menganggap bahwa
\end{abstract} fenotipe biofilm sebagai sarana untuk pertahanan diri dari stres lingkungan yang tak terduga pada permukaan tanaman. Kegiatan komersial biasanya menggunakan treatment 3 kali pencucian dan disinfektan untuk membersihkan sayur-sayuran dan buah-buahan. Proses sanitasi konvensional untuk membersihkan produk berdaun ini hanya mampu mengurangi tingkat patogen dengan jumlah yang tidak cukup memadai untuk memastikan keamanan pangan secara mikrobiologi. Ketidakmampuan ini disebabkan oleh lapisan mikroba yang kuat melalui biofilm. Untuk mengurangi keberadaan biofilm pada produk berdaun adalah dengan strategi mencucinya menyeluruh lebih dari 3 kali dan strategi sanitasi yang baik diperlukan untuk mengatasi biofilm ${ }^{2}$.

\section{STRATEGI MENGONTROL BIOFILM UNTUK KESEHATAN MASYARAKAT}

Konsumsi sayuran yang berupa
daun-daunan dan buah-buahan,
penggunaan peralatan medis secara
bergantian, talenan dapur, dan wastafel
dapat meningkatkan kejadian infeksi yang
terkait dengan biofilm. Penting untuk
dicatat bahwa infeksi ini tidak hanya sulit
untuk diobati, tetapi juga dapat
meningkatkan penyebaran gen resistensi

antibiotik antar mikroba sehingga ketika mikroba tersebut menginfeksi manusia maka infeksinya menjadi sulit untuk diobati dengan antibiotik konvensional. Selain itu, strain mikroba yang avirulen dalam biofilm dapat menjadi virulen karena menerima gen resisten. Penyebaran mikroba pembentuk biofilm memiliki beberapa dampak penting bagi kesehatan masyarakat karena mereka dapat menjadikan manusia menjadi lebih sakit untuk waktu yang lebih lama. Sayangnya, sistem kekebalan tubuh inang tidak mudah menangkal penyakit yang terkait dengan biofilm begitu halnya biosida termasuk antimikroba. Sebagai konsekuensinya, infeksi terkait biofilm dapat berlangsung dalam jangka waktu yang lama (berlangsung dari infeksi akut hingga infeksi kronis), sehingga menjadi masalah kesehatan masyarakat yang menakutkan.

Untuk mengurangi infeksi terkait biofilm ada yang perlu diperhatikan oleh instansi pemerintah dengan menginstruksikan kepada seluruh pemerhati kesehatan masyarakat dan lingkungan untuk mengembangkan dan mengembangkan penilaian risiko kesehatan yang tepat dan pedoman khusus infeksi terkait biofilm yang melindungi kesehatan masyarakat sekaligus lingkungan. 
Diperlukan penelitian lebih lanjut untuk evaluasi berbagai strategi untuk mengontrol biofim baik untuk mencegah atau penanggulangan kolonisasi biofilm pada permukaan, dan pengembangan metode baru untuk efisiensi pengobatannya.Penelitian juga harus fokus pada peran biofilm dalam perkembangan resistensi terhadap antimikroba, biofilm sebagai sumber organisme patogen, dan peran biofilm dalam penyakit kronis ${ }^{2}$.

Beberapa penelitian telah mencoba strategi lain untuk mengendalikan dan mencegah pembentukan biofilm. Lequette 21 menganalisis efisiensi penghilangan polisakarida dan enzim proteolitik terhadap biofilm spesies bakteri yang ditemukan dalam industri makanan. Winkelstroter ${ }^{10}$ menganalisis penggunaan molekul antimikroba dikenal yang dikenal sebagai bakteriosin dan ada peneliti menemukan potensi penggunaan bakteriosin untuk mempengaruhi pembentukan biofilm oleh Listeria monocytogenes. Sudah dievaluasi Efek anti-biofilm dengan minyak esensial (Essential Oil) dari peppermint (Mentha piperita) dan sereh (serai) terhadap pembentukan biofilm oleh $S$. enterica serotipe Enteritidis S64 ${ }^{21}$. Baru-baru ini telah diteliti kelimpahan relatif ekstraseluler dan protein terkait sel dinding (exoproteome), protein sitoplasma (proteome), dan ciri fenotipe dari Lactobacillus plantarum yang tumbuh pada kondisi planktonik dan biofilm kondisi. Genomik, proteomik dan metabolomik merupakan pendekatan baru untuk mempelajari biofilm. Analisis mereka telah secara ekstensif digunakan untuk skrening dan untuk mengidentifikasi gen, protein dan metabolit terkait dengan pembentukan biofilm ${ }^{23}$. Penelitian dilapangan akan meningkatkan informasi tentang jalur regulasi biofilm dan akan merangsang penemuan dan pengembangan strategi baru untuk mengontrol mikroorganisme dalam biofilm ${ }^{10}$.

\section{DAFTAR PUSTAKA}

1. Tibor, D., 2008. Handbook of Food Spoilage Yeast. $2^{\text {Edition }}$. Taylor and Francis Group. New York, USA

2. Mahami, T. and Adu-Gyamfi, A. 2011. Biofilm-associated infections: public health implications. International Research Journal of Microbiology (IRJM) (ISSN: 2141-5463) Vol. 2(10) pp. 375-381.

3. Riemann, H.P. and Cliver, D.O, 2006. Foodborne Infections and Intoxications, Third Edition. Elsevier. USA

4. O’Toole, G., Heidi, B., Kaplan, H.B., and Kolter, R. 2000. Biofilm Formation As Microbial as Microbial Development. Annu. Rev. Microbiol. 2000. 54:49-79 
5. Jamal, M., Tasneem1, U., Hussain, T. and Saadia Andleeb S. 2015. Bacterial Biofilm: Its Composition, Formation and Role in Human Infections. Research \& Reviews: Journal of Microbiology and Biotechnology. RRJMB | Volume 4 | Issue 3 | July-September, 2015

6. Veerachamy, S., Yarlagadda, T., Manivasagam, G. and Yarlagadda, P.K. 2014. Review Article: Bacterial adherence and biofilm formation on medical implants: A. Proc IMechE Part H: J Engineering in Medicine

7. Bogino P.C., Oliva M.M, Sorroche F.G, and Giordano W. 2013. Review: The Role of Bacterial Biofilms and Surface Components in Plant-Bacterial Associations. Int. J. Mol. Sci. 2013, 14, 1583815859;

doi:10.3390/ijms140815838

8. Rabin, N., Zheng, Y., Temeng, C. O., Du, Y., Bonsu E. \& Sintim H.O.2015. Review part of Agents that inhibit bacterial biofilm Formation. Future Med. Chem. (2015) 7(5), 647-671

9. Faria, S., Joao, I., and Jordao, L. 2015. Review Article:General Overview on Nontuberculous Mycobacteria, Biofilms, and Human Infection. Hindawi Publishing Corporation.Journal of Pathogens. Volume 2015, Article ID 809014 , 10 pages.http://dx.doi.org/10.1155/20 $\underline{15 / 809014}$
10. Winkelstroter L.K., Tulini F.L., De Martinis E.C.P. 2015. Identification of the bacteriocin produced by cheese isolate Lactobacillus paraplantarum FT259 and its potential influence on Listeria monocytogenes biofilm formation. LWT - Food Science and Technology 64: 586-592

11. Rosenvinge, E.C., O’May, G.O., Macfarlane, S., Macfarlane, G.T. \& Shirtliff, M.E. 2013. Minireview :Microbial biofilms and gastrointestinal diseases. Pathogens and Disease (2013), 67, 25-38.

12. Simo es a,M., Simo es b, L.C., Vieira, M.J. 2010. A review of current and emergent biofilm control strategies Food Science and Technology. 43 (2010) 573-583

13. Deb, M., Gupte S., Aggarwal P., Kaur M., Manhas A., Bala M., and Kant R. 2014. Microbial Biofilms. SMU Medical Journal, Volume 1, No. 2

14. Mittelman MW (1996). Adhesion to biomaterials. In: Fletcher $\mathrm{M}$, editor. Bacterial adhesion: molecular and ecological diversity. New York: Wiley-Liss, Inc; pp. 89-127.

15. O'Gara, J.P. 2007. Minireview: ica and beyond: Bioflm mechanisms and regulation in Staphylococcus epidermidis and Staphylococcus aureus. FEMS Microbiol Lett 270 (2007) 179-188. Federation of European Microbiological Societies Published by Blackwell Publishing Ltd. 
16. Eftekhar, F. and Dadaei, T. 2010. Biofilm Formation and Detection of IcaAB Genes in Clinical Isolates of Methicillin Resistant Staphylococcus aureus. Iranian Journal of Basic Medical Sciences Vol. 14, No. 2, Mar-Apr 2011, pp. 132-136

17. Marcinkiewicz, J., Strus, M., and Pasich N. 2013. Antibiotic resistance: a "dark side" of biofilm-associated chronic infections. POLSKIE ARCHIWUM MEDYCYNY WEWNĘTRZNEJ 2013; 123

18. Jordan D (2007). Antimicrobial resistance in animal and impacts on food safety and public health. In Focus, 28(4):163-164.

19. Fett WF, Cooke PH. 2003. Scanning electron microscopy of native biofilms on sprouts. Can. J. Microbiol. 49:45-54.
20. Sivaplalasinggam, S. Friedman, D.R., Cohen, L., Tauxe, R.V. 2004. Fresh produce a growing cause of outbreak of food borne illness in the United State 1973 through 1997. Food Prot. 67:2342-2353.

21. Lequette Y., Boels G., Clarisse M., Faille C. 2010. Using enzymes to remove biofilms of bacterial isolates sampled in the foodindustry. Biofouling 26: 42131.

22. Valeriano C., Oliveira T.L.C., Carvalho S.M., Cardoso M.G., Alves E. 2012. The sanitizing action of essential oil-based solutions against Salmonella enterica serotype Enteritidis S64 biofilm formation on AISI 304 stainless steel. Food Control 25: 673-677.

23. De Angelis M., Siragusa S., Campanella D., Di Cagno, R., Gobbetti R. 2015. Comparative proteomic analysis of biofilm and planktonic cells of Lactobacillus plantarum. DB200. Proteomics 15: 2244-2257.

Reviewer

dr. Pratika Yuhyi Hernanda, M.Sc., Ph.D 